\title{
Erratum to: Jewish Nonprofit Organizations in the U.S.: A Preliminary Survey
}

\section{Paul Burstein}

Published online: 20 February 2011

(C) Springer Science + Business Media B.V. 2011

\section{Erratum to: Cont Jewry \\ DOI 10.1007/s12397-010-9028-5}

Author would like to replace the two full paragraphs beginning with "The 1927 study...." with the below text:

The 1927 study was not repeated, and it is easy to imagine why. In 2001 the Research Department of United Jewish Communities conducted a census of American synagogues (reported in Schwartz, Scheckner, and Kotler-Berkowitz 2002). This was no simple matter; a tremendous amount of conceptual and methodological work had to be undertaken before the census itself could even begin. Two of the authors, Jim Schwartz and Jeffrey Scheckner, remarked elsewhere (Jones et al. 2002, p. 535) that "The process [of planning and conducting the census] was far more complicated and cumbersome than anticipated..." Given their experience, it is clear that the effort required to describe all, or even most, Jewish organizations would be truly staggering.

Author would also like to add the below reference to the "References" list:

Schwartz, Jim, Jeffrey Scheckner, and Laurence Kotler-Berkowitz. 2002. Census of U.S. synagogues, 2001. In The American Jewish year book, ed. David Singer and Lawrence Grossman. New York: The American Jewish Committee.

The online version of the original article can be found under doi:10.1007/s12397-010-9028-5.

P. Burstein $(\bowtie)$

Department of Sociology and Jewish Studies Program, University of Washington, Seattle, WA 98195-3340, USA

e-mail: burstein@u.washington.edu 